\title{
Molecular Screening of Hemoglobin D Variant in Anemia Patients of Eastern UP Population, India
}

Rai V'*, Yadav $\mathbf{U}^{1}$, Kumar $\mathbf{P}^{1}$, Mishra $\mathbf{O P}^{2}$ ${ }^{1}$ Department of Biotechnology, VBS Purvanchal University, J aunpur, India

${ }^{2}$ Department of Pediatrics, Banaras Hindu University, India

*Corresponding author: Vandana Rai, Department of Biotechnology, Human Molecular Genetics Laboratory, VBS Purvanchal University, J aunpur-222003, India

Received: January 25, 2021; Accepted: February 26, 2021; Published: March 05, 2021

\begin{abstract}
Hemoglobinopathy is the commonest inherited monogenic disorders, which are highly prevalent in India. The three most predominant hemoglobinopathies are $\mathrm{HbS}, \mathrm{HbE}$, the aim of the present study is to determine the frequency of $\mathrm{HbD}$ in Eastern UP population. After taking written consent, blood samples was collected from 350 individuals and genomic DNA was extracted from a the collected blood samples. PCR-RFP method was used to analyze the mutation. Out of 350 samples analyzed, one individual was heterozygous $\left(\mathrm{Hb}^{\mathrm{D} / \mathrm{N}}\right)$ and two individuals were homozygous $\left(\mathrm{Hb}^{\mathrm{D} / \mathrm{D}}\right)$ for $\mathrm{Hb} \mathrm{D}$ mutation. In conclusion, the overall $\beta^{D}$ allele frequency in Eastern Uttar Pradesh was observed as $0.71 \%$.
\end{abstract}

Keywords: Hemoglobin D; HB D; PCR-RFLP; EcoRI

\section{Introduction}

Inherited hemoglobin disorders are important health problem in developing countries including India. The cumulative gene frequency of haemoglobinopathies in India is $4.2 \%$ [1-3]. The commonest hemoglobin variants are $\mathrm{HbS}, \mathrm{HbE}$ and $\mathrm{HbD}$. The incidence of hemoglobin $\mathrm{D}$ as a whole is relatively low in India. The average prevalence of hemoglobin $\mathrm{D}$ gene is around $1 \%[3,4]$. The mutation responsible for $\mathrm{HbD}$ is point mutation in $\beta$-globin chain $\left(\beta^{121} \mathrm{G}\right.$-$>\mathrm{C}$ ). The gene frequency varies between $0.1 \%$ to $3.6 \%$ in different populations of India, the highest being represented by the states of Punjab (3.65), Jammu and Kashmir (3.3\%), and Uttar Pradesh (2.3\%) [3]. In this study, we aimed to determine the $\mathrm{HbD}$ mutation in the Eastern UP state population.

\section{Materials and Methods}

The study was approved by the Institutional Ethics Committee of VBS Purvanchal University, Jaunpur, India and all participants gave their written informed consent. $2 \mathrm{ml}$ blood sample was collected from 350 anemic patients from three districts of Eastern Uttar Pradesh-Jaunpur, Varanasi and Allahabad. Out of 350 samples, 50 samples were of Muslims, 100 from Scheduled cast, 100 from Brahmin and 100 samples from Other Backward Caste (OBC). Genomic DNA was extracted using the standard method of Bartlett and White [5]. HbD mutation analysis was done by PCR-RFLP method. PCR was carried out using codon 121 specific PCR primers and amplicon was subsequently digested by EcoRI restriction enzymes. 2 ug of template DNA, 4pM of each oligonucleotide primer (Forward: 5'-CAATGTATCATGCCTCTTTGCACC-3'; Reverse: 5' 5'-GAGTCAAGGCTGAGAGATGC AGGA-3'), 250 $\mu \mathrm{M}$ dNTP mix, 1.5U Taq buffer, 1 unit of Taq DNA polymerase and $0.1 \%$ Triton X 100 (Bangalore Genei Pvt. Ltd., India) in a total volume of $15 \mathrm{ul}$. The thermal cycling was carried out for denaturation of template DNA at $94^{\circ} \mathrm{C}$ for $1 \mathrm{~min}$., primer annealing at $65^{\circ} \mathrm{C}$ for $1 \mathrm{~min}$ and primer extension at $72^{\circ} \mathrm{C}$ for $1 \mathrm{~min}$ for 30 cycles. In the last cycle, primer extension was prolonged for $3 \mathrm{~min}$. The PCR products were subjected to electrophoresis using agarose (Sigma Co., USA). The purified PCR product was digested by restriction enzyme EcoRI and electrophoresed using $2 \%$ agarose gel and analyzed on a UV-transilluminator.

\section{Results and Discussion}

HbD (codon 121) specific primers amplified 861 bp long DNA amplicon (Figure 1). In case of normal $\beta$-globin allele, EcoRI enzyme cleave $861 \mathrm{bp}$ long amplicon in to 552 and $309 \mathrm{bp}$ long fragments. HbD mutation demolished EcoRI site. $\beta^{\mathrm{D}}$ allele remain uncut after EcoRI digestion (Figure 2). Out of 350 anemia samples, in one individual, $\mathrm{HbD}$ mutation was found in heterozygous $\left(\mathrm{Hb}^{\mathrm{D} / \mathrm{N}}\right)$ condition and two individuals were homozygous for $\mathrm{HbD}$ mutation (Figure 2). The overall $\beta^{\mathrm{D}}$ allele frequency in Eastern Uttar Pradesh was observed as $0.71 \%$. Mutant homozygous $\left(\beta^{\mathrm{D}} / \beta^{\mathrm{D}}\right)$ and heterozygous $\left(\beta^{\mathrm{A}} / \beta^{\mathrm{D}}\right)$ genotype percentage was $0.57 \%$ and $0.28 \%$ respectively. Out of two

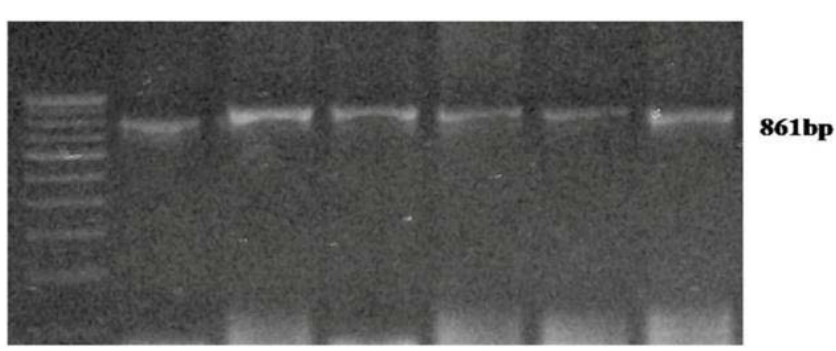

Figure 1: Gel picture showing 861bp of $\mathrm{HbD}$ amplicon.

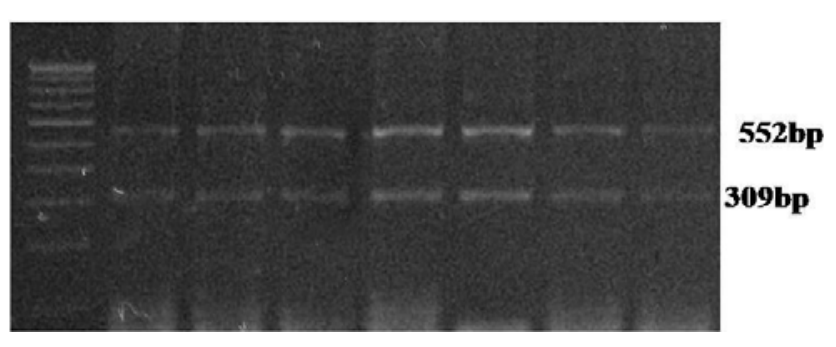

Figure 2: Gel picture showing EcoRI digested HbD amplicon.
Citation: Rai V, Yadav U, Kumar P, Mishra OP. Molecular Screening of Hemoglobin D Variant in Anemia Patients of Eastern UP Population, India. Ann Hematol Oncol. 2021; 8(2): 1330. 
homozygous individuals, 1 individual was SC and second individual was muslin. The $\beta^{\mathrm{D}}$ frequency in SC and Muslim caste were observed as $1.5 \%$ and $2 \%$ respectively. The results of present study were well comparable with the findings of previously published article $[3,6]$.

Lack of knowledge regarding $\beta^{\mathrm{D}}$ allele prevalence, poor facilities for their diagnosis, inability to carry out genetic counseling and presence of only occasional centers for prenatal diagnosis have resulted in failure of community control of birth of $\mathrm{HbD}$ in Eastern part of Uttar Pradesh.

\section{Acknowledgement}

Authors wish to thank all of the patients who participated in this study. This work was supported by a grant from Council of Scientific and Industrial Research, Government of India to VR (No 27(0204)/09/EMR-II).

Submission declaration and verification: This work has not been published previously and also not under consideration for publication elsewhere.

\section{Author's Contribution}

VR: Concept and design, drafting the article, interpretation of data.
UY: Sample collection, analysis.

PK: Interpretation of data, article drafting.

OPM: Provided samples, article drafting.

\section{References}

1. Agarwal MB. The Burden of Haemoglobinopathies in India-Time to Wake Up?. JAPI. 2005; 53: 1017-1018.

2. Balgir RS. Spatial distribution of red cell hemoglobin D variant in India. Indian Practr. 1995; 48: 128-135.

3. Balgir RS. Genetic epidemiology of the three predominant abnormal haemoglobins in India. J Assoc Physicians India. 1996; 44: 25-28.

4. Agarwal MB, Mehta BC. Genotypic analysis of symptomatic thalassemia syndromes (A study of 292 unrelated cases from Bombay). J Postgrad Med. 1982; 28: 1-3.

5. Bartlett JM, White A. Extraction of DNA from whole Blood. In: Bartlett, JMS and D Stirling, editors. Methods in Molecular Biology, PCR Protocols. $2^{\text {nd }}$ edition. Totowa New Jersey: Humana Press Inc; 2003: 29-31.

6. Balgir RS, Sharma SK. Distribution of sickle cell hemoglobin in India. Indian J Hemat. 1988; 6: 1-14. 